\title{
ESL Games+: A Modern Online Game in Teaching Vocabulary for Young Learners
}

\author{
Deva Septida \\ ${ }^{1}$ University of Bengkulu, Bengkulu, Indonesia devaseptida123@gmail.com
}

\begin{abstract}
Recently, online game becomes the most popular and favorite thing among children. Using online games in teaching English for children, especially vocabulary is a new modern and innovative method to foster their vocabulary mastery through their interest. Teaching through games will help teachers to make a very good atmosphere that can enhance the students' motivation to learn the language. Describes how to use online games (ESLGames+) to teach vocabulary for young learners as well as the teaching procedure which is divided into three stages of teaching; pre-activity, whilst-activity, and post-activity. To conclude, learning vocabulary through ESLGames+ website of online games is one effective and interesting way that can be applied in teaching vocabulary for young learners.
\end{abstract}

\section{Keywords: ESLGames+ Online games, Vocabulary, Young Learners}

\section{INTRODUCTION}

In non-English speaking countries, children that aged between 6 - 11 years old usually do not have sufficient reading or writing ability so that it becomes a significant challenge for English teachers. This is increasingly burdensome because there are still limited teaching materials for students of that age range. This certainly becomes an obstacle when the English learning process finds a large gap in the learning phase.

Hadfild (1996) points out that there is a slightly difference between teaching English to children and educating English to teenagers or adults. Other than not having adequate reading and writing skills, the children are also large differences in characteristics in terms of cognitive, interests, needs, and environment. The above challenges make teachers to use learning approaches that are accessible and agreeable in learning English lessons for young students. It is very essential for teachers to know the characteristics of children to create an effective teaching and learning process. One of important thing to create effecting process in teaching young learners is teaching technique.

Nowadays, young learners are mostly digital native children. They tend to use any kind of technology in their daily life which provide many kind of application they can use for typing, browsing, playing movie, video and music, and also game. Game is an effective method to motivate students to be more active in teaching and learning process. Moreover, game also can make the students to be more creative and interested in learning English. Allen (1983) said that "Games are helpful because they can make students feel that certain words are important and necessary." So, the aim of recommending games for vocabulary learning is to create conditions which encourage vocabulary expansion, and a wellchosen game can help the students acquire English words.

Recently, online game becomes the most popular and favorite thing among children. Using online games in teaching English, especially the vocabulary to young learners is a new modern and innovative method to foster their vocabulary mastery through their interest. By using games teachers will create an atmosphere that will enhance the students' desire to learn the language. Game which is one of teaching technique for young learners can make them enjoy the learning process since its colorful animated games as well as having amazing background music. Games are supposed to make students enjoy the learning process, as well as easier to understand the meaning of certain vocabulary. It is supported by Ersoz (2000) who believes that games are highly motivating in foreign language teaching because they are amusing and interesting they can be used to give practices in all language skills and can be used to practice all types of communication.

As one kind of interesting online game for students as young learners and teachers in teaching vocabulary, ESLGames+ can be easily accessed. ESLGames+ is an online platform which provides some kinds of teaching media that can be an alternative to teach English vocabulary. This platform provides such kinds of games, quizzes, videos, and PPT/Printables sheets. It also recommends some task/ worksheet that is useful for the students to practice English at home or in the classroom. For the teachers, however, need more convincing reasons to achieve what they have planned, and the goals or 
objective of learning. Therefore, teachers need to consider which games will use, when to use it, how to link them up with the syllabus, textbook or programs and how, more specifically, different games will benefit students in different ways. This paper describes how to use online games (ESLGames+) to teach vocabulary for young learners as well as the lesson plan.

\section{The Characteristics of Young Learners}

The junior learners or youngsters have their own features, which are totally different from elders. These characteristics include their way of thinking, their attitude, their talents, and other visible features. The way they learn languages is not much different from how they learn other knowledge. The principle above indirectly becomes a way to approach their world. To provide the finest excellence of coaching English to the children, the educators should recognize and comprehend the children way.

Brumfit and Tongue (1997) gives a list of the characteristics which young learners share. First, they have just begun their school life. This implies that the instructors have a great opportunity to sketch their presumptions of life school. Secondly, as a crowds, the children are much more dissimilar than elder or adult learners. Children are about to their varied home cultures, and relatively new to the order increasingly imposed on the cultural grouping by schools.

Next, children known as keen and enthusiastic learners. Fourth, their instructional can be closely connected with their development of ideas and thoughts, because it is so close to their initial experiences of formal teaching. In the last place, children need physical effort and activity as much as motivation for their rational process, and the closer together these can be the better.

In the context of language learning, it is expected that the young students will learn a foreign language more efficiently under certain circumstances. Consequently, there are several considerations that should be made when teaching English as a foreign language to young learners, such as: learning should be fun and natural, using sounds before written symbols in teaching the language for the first stage, and beginning with what the students already recognize to inspire association.

\section{Teaching Vocabulary for Young Learners}

Vocabulary is a very crucial element of language that helps students in mastering four skills in English, namely: listening, reading, speaking, and writing. Richards and Renandya (2002) stated that vocabulary is a main aspect of language proficiency and provides much of the basis of how well learners listen, speak, read and write. It is essential to have appropriate knowledge about vocabulary. Vocabulary mastery can be an indicator of student's success in learning English. It will be easy for students to express their ideas, emotions and opinions in English if they master a large number of vocabularies. Furthermore, having abundant of words can also help them to create some sentences to compose some kinds of texts in English. Moreover, those who have very few of vocabulary will face some difficulties in reading. They tend to stop reading and consult to the dictionary frequently as it is said by Edward (2006). Vocabulary is also important in language acquisition. Teaching vocabulary can help students to acquire the language easily. It also helps them to practice the structure more easily. It is important for young learners to communicate in daily basis and will strengthen their belief that English can be applied to convey the same ideas or feelings they demonstrate in their mother language (Finocchiaro, 1974).

It is essential for a teacher to master the ability of language in simple English in teaching vocabulary to young pupils. Furthermore, the instructors are also expected to introduce the language based on the right context because teaching English in children's level is quite different from teaching English in adult's level, especially in terms of acquiring vocabulary. A clear explanation is really needed in teaching the word and its meaning. Thus, the teacher should use an appropriate teaching technique. As it is said by nation (1982) that a good vocabulary teaching technique should attract the students attention, making them notice about the form, meaning and use of the word and give time for repetition.

\section{METHOD}

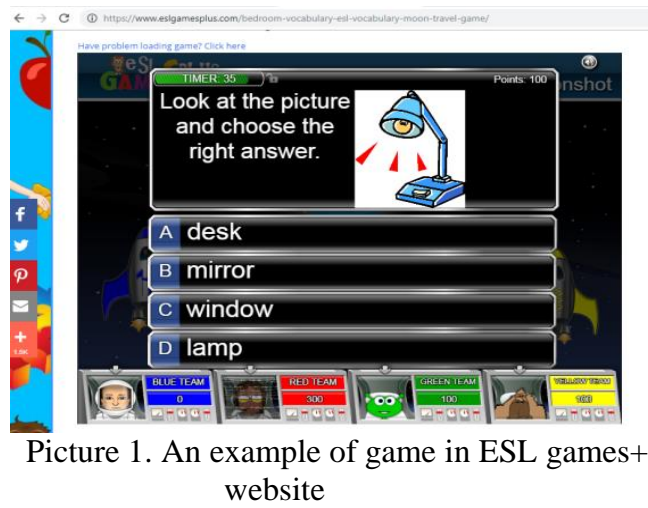

Games can give benefits for language learning. It creates an enjoyable and relaxing atmosphere of language learning. The students will get a chance to utilize language in a stress-free approach after learning and practicing new vocabulary (Uberman, 1998). When they play games, their attention is on the message, not the language itself. Instead of focusing on the precision of linguistic forms, most part of the students will just prioritize on how to win the game. It decreases the fear of negative evaluation, the concern of being negatively judged in public, and which is one of the main factors inhibiting language learners from using the target language in front of other people (Horwitz, Horwitz and Cope, 1986).

One of technology that the teachers can use is online games. Using online games in teaching vocabulary for young learners have some purposes: to help student when they give new words in English as foreign language; enrich their vocabulary; and help them to memorize those vocabulary easily. There are many websites that provide online games, those are depends on what kind of topics 
that will discuss or given to our students. The online games must be related with the topic or materials, and of course it must appropriate for students. Moreover, ESLGames+ becomes one of interesting website which provides many kinds of games and activities for teaching vocabulary to young learners.

There are many articles which supported that using games in teaching vocabulary is an effective way. As study by Huyen and Nga (2003) who found that games are effective in helping students to improve their vocabulary building skills. Similarly, Aslanabadi and Rasouli (2013) conducted a study on the effect of games on improvement of Iranian EFL vocabulary knowledge in kindergartens. The result of their study revealed that Games not only bring fun for learners to the class, but they also motivate learners and improve their confidence. Furthermore, Lewis and Bedson (1999) argued that games are popular among children because they like to play. Through games, young learners could interact, discover, and experiment with their surroundings. Using games not only enhances students' motivation, but also provide an incentive and stimulus to use the language.

\section{Results and Discussion}

There are three stages of teaching activity that can be used by the teachers to teach vocabulary for young learners through online games. The stages are pre-activity, whilst-activity, and post-activity. At the first stage, the students are guided to open the computer and one of online games websites that already prepared by the teacher. Next at the second stage they are doing their main activity in enjoying online games. The last part of the teaching stages is assessing students' ability of certain vocabulary by using the printable worksheet that is provided on the ESLgames+ online platform. Below is the step by step of teaching procedure using ESLgames+ online platform to teach vocabulary for young learners.

\section{Pre-activity}

1) Brainstorming is given by the teachers related to what kind of online games they often play and discuss a little of the advantages of playing online games regarding with learning English.

2) Some of vocabulary that often used in ESLgames+ online games are mentioned by the teachers.

3) The students are told what is going to do or the steps of learning activity.

Whilst-teaching

4) The students are asked to be ready to play an online games that already prepared by the teacher in each computer of classroom/laboratory.

5) The students are given 10 minutes to play the online game.

6) The students are asked to answer the worksheet that has been printed from ESLGames+ website, the worksheet must be discussed about the task related to the games played

\section{Post-teaching}

7) Both the teachers and the students are discussing the answers as well as giving the meaning of each vocabulary.

8) The students are asked to mention others vocabulary found in the game that are not appeared in the worksheet.

9) The feedbacks are given to the students regarding with their achievement and motivation for future learning.

\section{CONCLUSION}

The unique characteristic of young learners urges teachers to give appropriate strategy to teach them especially in teaching vocabulary. They need an enjoyable, fun and interesting technique in learning a new language. Game is one of these suggested techniques. They will be fond of it if their skills of English, their age group, their needs are fully-covered. Moreover, it will be even more effective if they play it in ways that are more cooperative than very competitive ways which frustrated many students after the game. Games also provides the youngsters a fun-packed and high-spirit learning atmosphere. For achieving the most from vocabulary games, the game selection plays an important role. One of suitable games is ESLGames+. This online platform website can be used by English teachers to teach vocabulary. To conclude, learning vocabulary through ESLGames+ website of online games is one effective and interesting method that can be utilized in teaching vocabulary for young learners.

\section{REFERENCES}

Allen, F. A. 1983. Techniques in teaching vocabulary. New York: Oxford University Press.

Aslanabadi, H., \& Rasouli, G. (2013). The effect of games on improvement of Iranian EFL vocabulary knowledge in kindergartens. International Review of Social Sciences and Humanities, 6(1), 186-195

Brumfit, C., Moon, J,. and Tongue, R.1997.Teaching English to Children. From Practice to Principle. Collins ELT: Longman.

Edwards, S. 2006. 50 Ways to improve your study habits. Golden Book Centre.

Ersoz, A. (2000). TEFLgames.com. Retrieved May 1st, 2019, from Six Games for the EFL/ESL Classroom: http://www.teflgames.com/why.html

Finocchiaro, marry.1974.English as a Second Language from Theory to Practice. New York: Regent Publishing Company

Hadfield, J (1996). Elementary communication games. Longman: Addison Wesley Longman Ltd

Horwitz, E. K., Horwitz, M., \& Cope, J. (1986). Foreign language classroom anxiety. Modern Language Journal, 70(1), 125-132.

Lewis, G., \& Bedson, G. (1999). Games for children. New York: Oxford University Press. 
Nation, I. S. P. (1982). Beginning to learn foreign vocabulary: A review of the research. RELC Journal, 13, 14-36.

Nuyen, N.T.T. \& Nga, K.T.T. 2003. The effectiveness of learning vocabulary through games. Asian EFL Journal 5. http://www.asian-efljournal.com/dec_03_sub.Vn.html

Richards, J.C. and Renandya, W.A. 2002. Methodology in Language Teaching :An Anthology of Current Practice. New York: Cambridge University Press.

Uberman, A. 1998. The Use of Games: for Vocabulary Presentation and Revision. English Teaching Forum 36 (1) 